Ana Makišová

UDK: 811.162.4’367.633:811.163.41’367.633

Jana Kováčová

Originalni naučni rad

Univerzita v Novom Sade

Filozofická fakulta

\title{
PREDLOŽKY DO, OD A Z V SLOVENČINE A ICH EKVIVALENTY V SRBČINE*
}

V práci sme výskum zamerali na primárne predložky od, do a z v slovenčine a ich ekvivalenty v srbčine. Spomínané predložky patria do skupiny primárnych predložiek a v oboch skúmaných jazykoch sa viažu s genitívom. Predložky od a do sú v oboch jazykoch formálne a zvukovo úplne zhodné. Slovenská predložka do je kontaktová a vyjadruje uskutočňovanie kontaktu deja s vnútrom objektu. Srbská predložka do je pozičná. Spoločný význam v oboch jazykoch je význam časovej, miestnej a číselnej hranice. Predložkou do sa v oboch jazykoch vyjadruje časová, miestna a číselná hranica, smerovanie dovnútra, spôsob, miera, účel, ciel', prostriedok. Predložka od v oboch jazykoch patrí k pozičným predložkám, vyjadruje rušenie pozície deja vzhl'adom na blízkost' objektu. Vyjadruje priestorové alebo časové vychodisko, príčinu, dôvod, pôvod, spôsob, zretel', účel, ciel'. Predložka z sa zarad'ujeme ku kontaktovým predložkám, lebo vyjadruje rušenie kontaktu deja s vnútrom alebo s povrchom objektu. Predložka z v spojení s menom v genitíve vyjadruje miestne vzt’ahy, čas, pôvod, materiál, príčinu, dôvod, spôsob, mieru, prostriedok, zretel'. V práci sme uviedli aj javy interferencie, ked' pod vplyvom srbčiny sa použivajú v spisovnej slovenčine nenáležité predložkové konštrukcie.

Kl'účové slová: predložka, srbčina, slovenčina, interferencia.

V práci sa zameriame na výskum troch predložiek, od, do a z v dvoch geneticky príbuzných jazykoch, v slovenčine a srbčine, za účelom zist'ovania zhôd a odlišností, ktoré v týchto dvoch jazykoch existujú. Ide o synchrónne skúmanie, porovnávanie ich súčasného stavu a o kontrastívnu, alebo konfrontačnú analýzu, ktorá sa zameriava aj na zhody aj na rozdiely dvoch jazykov. Východiskovým jazykom bude slovenčina, na základe ktorej budeme hl'adat' ekvivalenty v srbčine. Odvolávat' sa budeme na kodifikované príručky jestvujúce v oboch jazykoch, slovníky a gramatiky, a všetky uzávery doložíme dokladmi zo súčasnej literatúry, v ktorej sa najvýstižnejšie odzrkadl'uje súčasný stav tejto problematiky v oboch jazykoch. Konkrétne ide o doklady z románu Dušana Mitanu Koniec hry a prekladu do srbčiny (Kraj igre) a tam, kde to bude potrebné, doklady doložíme

* Makisova.anna@gmail.com

Príspevok vznikol v rámci projektu č. 178017 Diskurzy menšinových jazykov, literatúr a kultúr v juhovýchodnej a strednej Európe, ktorý financuje Ministerstvo školstva a vedy Srbska. 
aj zo slovníkov. Zmienime sa aj o interferencii na dokladoch, ktoré sme čerpali z vojvodinských slovenských médií, prevažne z televízneho spravodajstva.

Ciel'om tohto výskumu je zistit' zhody a rozdiely v predložkových systémoch geneticky príbuzných a typologicky blízkych jazykov, ale najmä poukázat' na relevantné rozdiely v sémantike slovenských a srbských predložiek, aby sa predišlo ich nenáležitému používaniu, $\mathrm{v}$ reči vojvodinských Slovákov a aby sa zároveň riešila otázka interferencie predložiek. Emil Horák vo svojej štúdii Východiská pre konfrontáciu predložkového systému slovenčiny s inými jazykmi (1989) píše, že pri konfrontácii predložkových systémov dvoch jazykov treba vychádzat’ zo štruktúrno-systémového opisu predložiek, v ktorom sa identifikuje vlastný význam predložky a ktorý poskytuje obraz o fungovaní predložiek v reči. Okrem tohto, existuje aj lexikografický opis predložiek, ktorý sa uvádza vo výkladových slovníkoch. Takýto výklad vychádza z predpokladu, že sú predložky synsémantické slová a že svoj význam nadobúdajú až v kontexte (význam miesta, času, spôsobu, príčiny, účelu, zretel'a atd'.). Mnohí jazykovedci, ktorí sa zaoberali konfrontáciou predložkového systému slovenčiny s niektorým cudzím jazykom vychádzali z Horákovho systému slovenských predložiek, vybudovaného na základe binárneho a ternárneho protikladu a používali štruktúrno-systémový opis. Napr. Nina Milecová (1989) sa zaoberala konfrontáciou predložkového systému slovenčiny a ruštiny, výchádzala zo systému kontaktových a pozičných predložiek v slovenčine a uvádzala ich ekvivalenty v ruštine. Eva Ružičková (1989) skúmala predložkový systém slovenčiny v konfrontácii s angličtinou, Ján Taraba (1989) s francúzštinou, Ján Kerd’o (1989) s rumunčinou. Podstatné je, že všetci sa opierali o Horákove výskumy. Aj ked' E. Horák konštatuje, že lexikografický opis nie je najvhodnejším podkladom pre konfrontáciu predložiek dvoch jazykov, v predloženej práci budeme vychádzat' i zo štruktúrno-systémového i z lexikografického opisu, lebo sú práve abstraktné významy, ktoré sa uvádzajú v lexikografických opisoch najčastejším zdrojom interferencie slovenčiny a srbčiny, najmä u ovládatelov oboch jazykov na území Vojvodiny, kde sú tieto jazyky v priamom kontakte. Základný, invariantný význam predložky, o ktorom sa hovorí v štruktúrno-systémovom opise (ide spravidla o priestorový význam) nepodlieha tak často interferencii ako niektoré iné, abstraktnejšie významy. A nakoniec, ak určíme invariantnému významu niektorej predložky v slovenčine presný ekvivalent $\mathrm{v}$ srbčine, neznamená, že ten ekvivalent bude vyhovovat' vo všetkých významových odtienkoch slovenskej predložke. A tak isto neznamená, že sa dve formovo rozličné predložky, ktoré nie sú významovými ekvivalentmi, ked’ ide o základný, invariantný význam, nemôžu významovo kryt' pri vyjadrovaní niektorého abstraktného významu. Situácia je vel'mi zložitá a preto, aj ked' na niektorých miestach v práci môže vyzniet', ako keby sme prekladali predložky z jedného jazyka do druhého, predsa sme si zvolili odvolávat' sa aj na lexikografický opis a hl'adat' (najčastejšie používané) ekvivalenty slovenským predložkám aj v tých abstraktnejších významoch.

Tak definície, ako aj celkový systém predložiek sú v oboch skúmaných jazykoch takmer identické. V gramatikách a morfológiách oboch jazykov sa predložky 
považujú za pomocné, nesamostatné, synsémantické slová, ktoré slúžia iba na vyjadrovanie vztahov (priestorových, časových a iných) medzi samostatnými slovami vo vete. Podl’a Morfológie slovenského jazyka: „Predložky čiže prepozície sú neohybné slová, ktoré v spojení s nepriamymi pádmi podstatných mien, zámen a čísloviek vyjadrujú okolnostné (adverbiálne), predmetové (objektové) a prívlastkové (atributívne) vzt’ahy.“ (Dvonč a kol., 1966: 619). V srbskej gramatike sa predložky definujú takto: „Predložky sú pomocné slová, ktoré slúžia na označovanie vztahov jednotlivých pádových tvarov slov s inými slovami vo vete, alebo na bližšie určovanie tých vzt’ahov“ (Stevanović, 1970: 379). Vzt’ahy, čiže významy, ktoré predložky v spojení s podstatnými menami určujú, sú: miesto, čas, spôsob, príčina, účel, zretel', prostriedok a predmet, ktorý je priamo alebo nepriamo zasiahnutý dejom. Priestorový vzt’ah je na prvom mieste medzi vzt’ahmi, ktoré vyjadrujú predložky a môže mat' miestne alebo smerové významy. Za nimi nasledujú časové vzt’ahy atd'.

O predložkovom systéme v slovenčine a srbčine písal Emil Horák (1971, 1973, 1989). V prácach konštatuje, že „Pomerne vysoký stupeň zhody v pláne formy na jednej strane a pomerne nízky stupeň zhody v pláne obsahu na strane druhej vyvoláva, totiž, a to najmä v pedagogickej praxi, celý rad špecifických problémov spojených s interferenciou.“ (Horák, 1973: 75). Ojedinele o predložkách písala A. Makišová (1990), ktorá svoj výskum upriamila na použivanie predložiek v ústnych prejavoch vojvodinských Slovákov.

\section{DO}

Medzi predložkou do v slovenčine a v srbčine existuje úplná formálna a zvuková zhoda, obe sa viažu s genitívom čo je príčinou, že pri osvojovaní si týchto jazykov, alebo ich paralelnom používaní, často nastáva interferencia. Význam týchto predložiek je však odlišný. Slovenská predložka do je kontaktová a vyjadruje uskutočňovanie kontaktu deja s vnútrom objektu. Vždy sa viaže s genitívom a môže vyjadrovat' rozličné významy. V Krátkom slovníku slovenského jazyka (d’alej KSSJ) sa uvádza sedem významov predložky do. Srbská predložka do je naopak pozičná a podl'a Rečnika srpskoga jezika (d’alej RSJ) vyjadruje pät’ významov s niekol'kými podvýznamami. Jediným spoločným významom v oboch jazykoch je význam časovej, miestnej alebo číselnej hranice.

\section{1. Časová, miestna alebo číselná hranica}

Spojením predložky do s genitívom možno označit' koncovú časovú, miestnu alebo číselnú hranicu. Z dokladov vyplýva, že slovenskej predložke je ekvivalentná v srbčine predložka do, napr. Do tretej musite byt triezvy ako rybička. Do tri da ste potpuno trezni. ... ...v matracoch má nadžganých tol'ko peňazí, kol'ko ty do smrti nezarobišs. ... u slamaricama ima naguranih para, koliko ti do smrti nećeš zaraditi. Kapitánovi poskočilo obočie hore, vysoko, až do polovice čela... Kapetanu su obrve poskočile nagore, visoko čak do polovine čela... Tvári sa, že nevie narátat' do pät'... Pravi se da ne ume da nabroji do pet... 
Základným významovým ekvivalentom slovenskej predložky do v srbčine je predložka u, a nie predložka do. Vo vyjadrovaní ostatných významov sa tieto dve zvukovo identické predložky nezhodujú, ale slovenskej predložke do je ekvivalentná $\mathrm{v}$ srbčine kontaktová predložkou u, ktorá sa spája s akuzatívom. Ide o vyjadrovanie nasledujúcich významov:

\subsection{Smer dovnútra niečoho alebo na niečo}

Predložkou do so slovesami pohybu vyjadrujeme smerovanie dovnútra niečoho, napr. Ked'si vyčistil zuby, nakvapkal do pohára naplneného zdravotne neškodnou kvapalinou prúdiacou $z$ vodovodu... Kada je oprao zube i nakapao u čašu tečnost iz vodovoda bezopasnu po zdravlje... Peter Slávik prešiel z kúpelne do obývačky... Petar Slavik je prešao iz kupatila u dnevnu sobu...

$\mathrm{Na}$ vyjadrenie smeru v srbčine sa používa aj predložka na. Vychádza sa z jazykového úzu, ktorý je v každom jazyku ustálený a musíme ho rešpektovat', rovnaká reália, rovnaký jav skutočnosti sa v dvoch jazykoch rozlične chápu a vysvetl'ujú, preto sa aj používajú rozličné predložky, napr.: ...dobre však vedel, že takáto primitivnost' by iba priliala olej do ohňa. Međutim, dobro je znao da bi takva primitivnost samo dolila ulje na vatru.

\subsection{Väzba pri slovesách}

Slovenskej predložke do pri väzbe so slovesami významovo je ekvivalentná v srbčine predložka u. Potvrdzujú to doklady: ...bola zasvätená do najmenšich podrobností......bila je upućena u najsitnije detalje... Pred rokom odišla do dôchodku... Pre godinu dana je otišla u penziju... ...bola do majstrovho sýteho barytónu už dlhé roky zamilovaná tak tajne... bila je već godinama zaljubljena u maestrov baršunasti bariton toliko tajno...

\subsection{Spôsob, miera, prostriedok alebo nástroj}

Ked' ide o vyjadrovanie týchto významov, slovenskej predložke do, okrem už spomenutej srbskej predložky u ekvivalentná je väzba do $+\mathrm{G}$, najmä ked' ide o vyjadrovanie miery. Pri vyjadrovaní prostriedku alebo nástroja je ekvivalentná aj väzba o+A, napr.: Aspoň tak hlúpo... do očí... prečo si stále vymýšlašs? Barem nemoj tako glupo... u oči... zašto stalno izmišljaš? ... a dlhé, do polovice chrbta padajúce vlasy jej zavírili okolo tváre. ... i duga kestenjasta kosa, koja je dosezala do polovine leđa, zatalasala joj se oko lica. Je dorazená do dna... Popijena do dna... ...začala už zháňat' aj drobné jemné vecičky, do ktorých sa obliekajú krásne škvŕñatá... ...počela je da nabavlja sve te stvarčice u koje se oblače prelepi bebironi... Utrel si špinavé ruky do plášta... Obrisao je prljave ruke o mantil... ...opatrne, nevidiš, že t’a láka do pasce? ...pažljivo, zar ne vidiš da te mami u stupicu?

\section{5. Účel, ciel'}

Pri vyjadrovaní účelu ako ekvivalent slovenskej predložke do v srbčine sú predložky na a za, čo by sme znovu mohli vysvetlit' vychádzajúc z úza v dvoch jazykoch, v ktorých sú rozličné odtienky vo vysvetl'ovaní si jednotlivých reálií a javov skutočnosti. Ide iba o nuansy v spôsobe vysvetlovania si javov skutočnosti, ktoré sú potenciálnym zdrojom interferencie, napr.: A tak zase do roboty. A tako, 
opet na posao. Otec naozaj písal do závodného podnikového časopisu... Otac je stvarno pisao za fabrički list... Vložil sa do práce s plným nasadením... Bacio se punom parom na posao...

Podl'a Morfologických aspektov súčasnej slovenčiny (d’alej MASS) predložkou do v ustálených spojeniach typu Čo t’a do toho? Čo nás do toho sa vyjadruje aj zretel'. V srbčine sú ekvivalentné ustálené bezpredložkové spojenia, napr. Šta nas briga.

\subsection{Interferencia}

Pod vplyvom srbčiny často používame spojenie „Íst' na robotu“ (v srbčine Ići $\underline{n a}$ posao). Namiesto predložky na treba použit' kontaktovú predložku do (ide o smerovanie deja): Íst' do roboty. Konkrétne v tomto, ale aj v mnohých iných prípadoch, $\mathrm{v}$ ktorých pod vplyvom srbčiny nastáva nenáležité používanie predložiek, interferencia nastáva kvôli odlišným vysvetlovaním si reálií a javov skutočnosti $\mathrm{v}$ dvoch jazykoch, čo u bilingvistov, ktorí pritom nepoznajú dôkladne situáciu $\mathrm{v}$ systéme jedného z používaných jazykov, vyvoláva mechanické uplatňovanie pravidiel dominantného jazyka. Je celý rad d’alších príkladov, na ktoré nemáme konkrétne jazykové vysvetlenie, lebo ide o mimojazykové záležitosti a preto si iba musíme osvojit', že sa to v dvoch jazykoch vyjadruje rozlične a dbat', aby sme nerobili chyby. Najčastejšie príklady na interferenciu tohto typu sú: „pracovat' $\underline{v}$

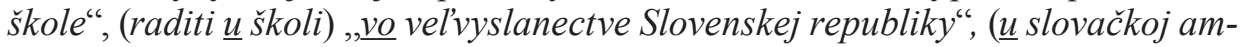
basadi), „dolievat’ olej na oheñ“, v (dolivati ulje na vatru), namiesto správnej väzby pracovat' na škole, na vel'vyslanectve, dolievat' olej do ohňa.

Interferencia často nastáva aj pri vyjadrovaní časovej hranice alebo času, v ktorom sa určitý dej uskutočňuje a to, čo vojvodinským Slovákom spôsobuje problémy, vôbec nie je predložka, ale substantívum, ktoré pri vyjadrovaní času a pod vplyvom srbčiny vel'mi často použijú v nesprávnom páde, čiže v akuzatíve, napr. „Popoludní sú žiaci v škole do šest’hodin“" (Myjavcová, 2009: 195), namiesto Popoludni sú žiaci v škole do šiestej (Myjavcová, 2009: 195).

\section{OD/ODO}

Predložka od si v oboch jazykoch vyžaduje väzbu s genitívom. V rámci štruktúry predložkového systému slovenčiny patrí k pozičným predložkám a vyjadruje „rušenie pozície deja vzhl’adom na blízkost' objektu“ (Horák, 1972: 347). Pri tejto predložke, rovnako ako aj pri iných predložkách končiacich sa na spoluhlásku, v oboch jazykoch nastáva asimilovaná výslovnost' v závislosti od hláskovej podoby začiatku nasledujúceho slova. $V$ slovenčine $\mathrm{v}$ genitíve jednotného čísla nastáva vokalizácia predložky pred zámenom ja a niektorými substantívami (odo mňa, odo dňa). V KSSJ sa uvádza šest' významov predložky od v spojení s genitívom a v RSJ devät' významov, pri niektorých s d’alšími významovými odtienkami. Takmer vo všetkých slovenských významoch sa táto predložka používa aj v srbčine. Ked' ide o interferenciu u vojvodinských Slovákov, problém nastáva preto, lebo nie všetkým srbským významom predložky od je ekvivalentná for- 
movo rovnaká predložka v slovenčine. Ostatným významom tejto predložky v srbčine, $v$ slovenčine zodpovedá predložka $\mathrm{z}$, alebo aj bezpredložková väzba, o čom budeme viac hovorit' v časti o interferencii. Predložkou od môžeme vyjadrit' tieto významy:

\subsection{Priestorové alebo časové východisko}

Pri vyjadrovaní času a priestoru slovenskej predložke od je ekvivalentná v srbčine predložka od, napr. ...ráno sa vrátim od matky... ...ujutru ću se vratiti od majke. Len cestou od autobusu som stretol dvoch bradatých. Samo usput od autobusa sreo sam dvojicu sa bradom. ... sl'uboval byt' hned'od rána plný napäta a nervozity... ...već od ranog jutra obećavao napetost i nervozu... Svetský mu umožnil zúčastňovat’sa na príprave inscenácie od samého začiatku... Svetski mu je omogućio da učestvuje u pripremama inscenacije od samog početka...

Predložkou od v spojení s podstatným menom v genitíve vyjadrujeme vzd’al'ovanie sa v priestore. K predložke od a substantívu v genitíve pripája sa zvyčajne sloveso s predponou od-: odbehnút' od okna, odist' od stola, odlepit' od podlahy. Spojením predložky od s genitívom sa ruší pozícia vytvorená v blízkosti nejakého miesta, napr. odchádzat'od stola, odíst od stola. Aj v srbčine predložkou od v spojení s podstatným menom $\mathrm{v}$ genitíve vyjadrujeme vzd’al'ovanie sa v priestore, napr. bežim od njega, pobeći od kuće.

Predložkou od sa v spojení s genitívom substantív označujúcich časové body alebo úseky vyjadruje časové východisko, začiatok, napr. Je taký od narodenia. Nevideli sme sa od detstva. Uvedeným spojením sa v srbčine tiež vyjadruje časový, začiatočný bod, napr. od rođenja, od glave.

\subsection{Prícina, dôvod}

Pri vyjadrovaní kauzatívneho vztahu, ked' ide o priamu vnútornú príčinu, sa predložka od v oboch jazykoch tiež úplne zhoduje. Najčastejšie sa viaže so substantívami pomenúvajúcimi psychické a fyziologické stavy a procesy, napr. Slávikovi sa od zhnusenia zdvihol žalúdok. Slaviku se od gađenja podigao želudac. ...nemohol predsa dúfat', že bude od radosti vyskakovat' po povalu... ...nije ni mogao da očekuje da će od radosti skakati do plafona... ...šarmantné boa z pštrosích pier, ktoré sa rozpadávalo od staroby... ...šarmantna peruška od nojevog perja, koja se raspadala od starosti...

\subsection{Pôvod, pôvodca}

Spojením predložky od a podstatného mena v genitíve možno vyjadrit' pôvod, napr. Chceš povedat, že je to od niekoho iného? Želiš da kažeš da je od nekog drugog? Bolo mu absolútne jasné, že zápal plúc vyvolá kniha, ktorú tam čital: Čarovný vrch od Thomasa Manna. Bilo mu je jasno da je upalu pluća prouzrokovala knjiga koju je upravom čitao: Čarobni breg Tomasa Mana. V srbčine v druhom doklade pôvod možno vyjadrit' aj bez predložky. V RSJ pri význame pôvodu sa uvádza doklad: Todor od Stalaća, od dobrog oca i od još bolje majke. V oboch jazykoch pôvod možno vyjadrit' aj v spojení od + sloveso s významovým okruhom pochádzania, napr. Kabát má od staršej sestry. Kaput ima od starije sestre. 


\subsection{Spôsob, prostredník, prostredníctvo, miera}

Predložka od v spojení s genitívom v slovenčine vyjadruje spôsob deja zväčša v ustálených spojeniach, napr. „,povedat' (niečo) od srdca, porozprávat' od slova doslova, hádat' od oka“ (MASS, 2010: 290). Rovnako je aj v srbčine, napr. „učiniti što od sveg srca“" (RSJ, 2007: 854). Mieru možno vyjadrit' aj spojeniami predložiek od - do, od - po, ktoré vyjadrujú vymedzenú, ohraničenú mieru. Rovnaké spojenia sú aj v srbčine, napr. ...ktoré zakrývali jednu stenu miestnosti od dlážky až po povalu... ...koje su prekrivale jedan zid od poda do plafona... Dnes mal $k$ dispozícii televizne štúdio od 15.00 do 18.00. Danas mu je televizijski studio bio u dispoziciji od 15.00 do 18.00, porozprávat presne od slova do slova, prist'zablatený od hlavy po päty, od kuće do škole, od početka do kraja.

\section{5. $V a ̈ z b a$}

V oboch jazykoch predložkou od vyjadruje sa väzbu so slovesami alebo menami, napr. ...ved' ja som robil strihača, ked' on ešte nerozoznal televizor od akvária. ... pa ja sam radio montažu dok on još nije razlikovo televizor od akvarijuma. ...oddelil bielok od žltka... ...odvojila belance od žumanca... To však závisí od náhody, na to nemám nijaký vplyv... To, međutim, zavisi od slučajnosti, na to nemam nikakav uticaj...

Pri niektorých slovesách pohybu sa spojením genitívu s predložkou od vyjadruje smer vzhl'adom na východisko deja alebo pohybu, napr. Fúka silný vietor $\underline{o d}$ severu. Od hôr sa valia vel'ké mraky. V srbčine sa spojením predložky od a substantíva v genitíve tiež vyjadrujeme smer, napr. ...od istoka duva vetar. Dolazi od njega.

Predložka od v spojení s genitívom sa používa so slovesami pomenúvajúcimi deje alebo stavy spôsobené živočíchmi, napr. Turisti boli doštípani od komárov. Otec je celý dopichaný od včiel. Turisti su bili izujedani od komaraca.

\subsection{Zretel'}

Predložka od vyjadruje zretel' v porovnávacích konštrukciách, napr. „byt' straší/mladší/lepší od niekoho“ (MASS, 2010: 293) a tiež aj „,pri hodnotiacich adjektívach, ked' sa k významu zretela pridružuje odtienok personálneho pôvodcu“ (MASS, 2010: 293). V srbčine sa rovnakou väzbou tiež môže vyjadrit' význam zretel'a, napr. ...ale bol to od nej vlastne dobročinný skutok. ...nego je to, zapravo, bio čin dobročinstva. Ale to ste od Petra a pár rokov staršia. Pa, vi ste od Petra stariji nekoliko godina. Oženil sa s kočkou, ktorá bola odo mňa o dva roky mladšia. ...oženio se ribom koja je od mene bila mlađa dve godine.

\section{7. Účel, ciel'}

„Spojením predložky vyjadrujeme účel s ciel’om zabránit' tomu alebo prekonat' to, čo je obsiahnuté vo význame substantíva v genitíve predpisat' (kvapky) od kašla, uživat' (lieky) od bolesti“ (MASS, 2010: 295). Pri vyjadrovaní účelu je predložka od synonymná s predložkou proti. V srbčine význam účelu sa vyjadruje predložkou od, napr. kutija od naočara, traka od pisaće mašine (RSJ, 2007: 853). 


\subsection{Interferencia}

Nie v každom prípade ako v srbčine môžeme používat' konštrukciu od $+\mathrm{G}$ v slovenskom jazyku. V srbčine sa vyskytuje častejšie a potom pod jej vplyvom aj $\mathrm{v}$ slovenčine ju použijeme tam, kde netreba. Častým zdrojom interferencie je vyjadrovanie miery, ktorá sa predložkou od môže vyjadrovat' iba v srbčine, napr. dete od šest godina. Niekedy sa v reči vojvodinských Slovákov vyskytne rovnaké spojenie „diet’a od šest' rokov“, ktoré je nesprávne a náležité spojenie bude šestročné dieta. V médiách sme zaznamenali aj tieto doklady: „Škody od požiarov" (šteta od požara); ,Lúdia, ktorí majú viac od 65 rokov, majú právo..." (Ljudi koji imaju više od 65 godina). Nenáležité spojenia treba vystriedat' týmito: škody spôsobené požiarmi alebo škody, ktoré spôsobili požiare. L’udia, ktorí majú viac ako 65 rokov. Predložka od sa v slovenčine môže použit' iba, ked' ide o vyjadrovanie zretel’a, napr. starší odo mňa (s ohl'adom na mňa, prirovnávajúc ho so mnou).

\section{3. $\mathrm{Z} / \mathrm{ZO}$}

Podl'a KSSJ predložka z v spojení s genitívom môže vyjadrovat' osem významov. Táto predložka nemá v srbčine formovo identický ekvivalent, ale významovo jej zodpovedajú srbské predložky iz a s/sa. V štruktúre predložkového systému slovenčiny ju zarad’ujeme ku kontaktovým predložkám, lebo vyjadruje rušenie kontaktu deja s vnútrom alebo s povrchom objektu (Horák, 1972). Viaže sa iba s genitívom. Srbská predložka iz sa tiež viaže iba s genitívom a vyjadruje rušenie kontaktu deja s vnútrom objektu. Predložka s/sa sa viaže s genitívom, ale aj s inštrumentálom a v tejto prvej väzbe ( $\mathrm{s} / \mathrm{sa}+\mathrm{G})$ vyjadruje rušenie kontaktu s povrchom objektu. V RSJ predložka iz v spojení s genitívom má desat' významov s d'alšími podvýznamami, z ktorých sú slovenskej väzbe z/zo $+\mathrm{G}$ väčšinou ekvivalentné významy miestnych vztahov, času, časového východiska, pôvodu, materiálu, príčiny, dôvodu, spôsobu deja, predmetu. Predložka s/sa v spojení s genitívom vyjadruje pät' významov s rozličnými odtienkami a takmer všetky sú ekvivalentné slovenskej väzbe z/zo + G. Hlásková podoba predložky z sa pravidelne vokalizuje a asimiluje v závislosti od hláskovej podoby začiatku nasledujúceho slova. Spodobovanie nastáva, ked' sa nasledujúce slovo začína neznelou spoluhláskou a vokalizácia v niekol'kých podmienkach: ked' sa nasledujúce slovo začína na rovnakú spoluhlásku (zo začiatku), podobnú podl'a znelosti (zo srdca), podl'a mäkkosti (zo žartu), podl'a znelosti a mäkkosti spolu (zo školy), alebo skupinu spoluhlások, v ktorej sa na druhom alebo tretom mieste nachádza rovnaká alebo podobná spoluhláska (zo vzduchu, zo psa). Pod rovnakými podmienkami nastávajú zmeny aj v srbčine. Významy predložky z/zo, ktoré sa uvádzajú v KSSJ sú nasledujúce:

\subsection{Miestne vztahy}

Významy týchto predložiek sa úplne zhodujú, ked' ide o vyjadrovanie rušenia kontaktu deja, bud'to z vnútra, alebo z povrcha objektu. V slovenčine sa oba významy vyjadrujú väzbou z/zo $+\mathrm{G}$ a v srbčine sa používa väzba iz $+\mathrm{G}$, ked' ide o rušenie kontaktu $s$ vnútrom objektu a väzba s/sa $+\mathrm{G}$, ak sa kontakt ruší s povrchom 
objektu, napr. Nakoniec vytiahol zo skrine l’ahkú letnú košelu pastelovočervenej farby. Na kraju je izvukao iz ormana tanku letnju košulju pastelnocrvene boje. ...ešte predtým, ako ju zdvorilo a slušne vyhodil zo svojho bytu... ...još pre nego što ju je učtivo i kulturno izbacio iz svog stana... ...rozoberal na súčiastky nebožtíkov, ktorí odišli z tohto sveta vd'aka svojim bližnym. ...bavio se rastavljanjem na delove pokojnika koji su sa ovoga sveta otišli zahvaljujući svojim bližnjim. ...dokrkvanou špinavou vreckovkou si utrel pot zz čela... izgužvanom prljavom maramicom obrisao znoj sa čela... Ak vyjadrujeme v slovenčine rušenie kontaktu $\mathrm{s}$ vnútrom objektu, predložka z sa často spája so slovesami s predponou vy-, napr. vytiahol, vyhodil. Pohyb zhora nadol v slovenčine vyjadrujeme spojením predložky z a mena v genitíve, napr. zoskočit' z koňa a v srbčine predložkou sa a mena v genitíve, napr. skočiti sa konja.

\section{2. Čas, časové východisko}

Časové východisko v srbčine vyjadruje predložka iz, ktorá je významovo ekvivalentná slovenskej predložke z/zo, ale v analyzovanom korpuse sa ako prekladový ekvivalent vyskytla aj príslovka s týmto významom, napr. Zo začiatku som vypĺnal chl'astom len krátke prestávky medzi robotou... Najpre sam cugom ispunjavao samo kratke pauze između posla... Podl'a svedectva vizitačnej zápisnice Izáka Abrahamidesa z roku 1611... Kako svedoči vizitacijski zapisnik Izaka Abrahamidesa iz 1611. godine...

Časové východisko v ustálených spojeniach sa v slovenčine vyjadruje spojením predložky z a mena v genitíve, napr. zo stredy na štvrtok, zo začiatku, z tých čias. V srbčine ekvivalentné predložky budú sa, iz.

\subsection{Pôvod, materiál}

Pôvod vyjadrujeme spojením predložky z a mena pomenúvajúceho substanciu v genitíve. Pri vyjadrovaní pôvodu alebo materiálu slovenskej väzbe z $+\mathrm{G}$ zodpovedajú väzby dvoch predložiek s rovnakým pádom - predložky iz (pôvod) a od (materiál, látku), napr. S kol'kými významnými l'ud’mi z umeleckej brandže sa pozná! S koliko značajnih ljudi iz umetničke brandže se poznaje! Pochádzal zo starého zemianskeho rodu... Poreklom sam iz stare veleposedničke porodice... ...boli to šaty z hodvábneho brokátu staroružovej farby... Bila je to haljina od crvenog brokata prljavoružičate boje... ...ked' si uvedomi, že osud l'udstva, osud celej tejto planéty, áno, aj jeho osud, osud tohto živého tela z mäsa a kostí... ...sudbina čovečanstva, sudbina čitave ove planete, da i njegova sudbina, sudbina ovog živog tela od krvi i mesa... ...bol to starý, dôverne známy tmavohnedý nábytok $\underline{z}$ orechového dreva... ...bio je to stari tamnosmeđi nameštaj od orahovine...

\subsection{Prícina, dôvod}

Pri vyjadrovaní príčiny sú slovenská predložka z a srbská predložka iz v spojení s genitívom ekvivalentné a používajú sa, ked’ ide o vyjadrovanie nepriamej príčiny, čiže ked' je slovo v genitíve iba stimulom, napr. Kúpil jej ich z čírej samopaše. Kupio ju je iz čistog hira. ...v podstate jej bol verný; skôr z pohodlnosti ako zo zásady... ... u suštini, bio joj je veran pre $\underline{i z}$ udobnosti nego iz principa... 
...všetci dobre vieme, že súdruh Slávik sa stal dezignovaným režisérom zo všeobecne známych príćin... ...svi dobro znamo da je drug Slavik postao imenovani režiser iz opšte poznatih razloga...

$\mathrm{V}$ niektorých prípadoch, slovenskej predložke z v závislosti od sémantiky substantíva, môže byt' ekvivalentná príčinná predložka od, napr. ,Žalúdok sa mi obracia z teba, rozumieš? “ „Želudac mi se prevrće od tebe, razumeš li? “ „To je peklo, z tej horúčavy by sa našinec zmagoril“... „, Ovo je pakao, od te vrućine će naš čovek šenuti “...

Podstatné meno v genitíve $\mathrm{v}$ spojení s predložkou z môže vyjadrovat' vnútorné pohnútky, napr. $z$ vd’ačnosti, z lásky v srbčine je ekvivalentná predložka iz v spojení s genitívom iz zahvalnosti, iz ljubavi.

\subsection{Spôsob, miera, sprievodné okolnosti deja}

$\mathrm{Na}$ základe uvedených dokladov pri vyjadrovaní spôsobu a sprievodných okolností deja slovenskej väzbe $\mathrm{z}+\mathrm{G}$ zodpovedá predložka s/sa a vo vyjadrovaní miery alebo intenzity predložka iz, obe v spojení s genitívom, napr. ...preskakovala $\underline{z}$ predmetu na predmet... ...skakala $\underline{s}$ teme na temu... ...obkl'učovali ich zo všetkých strán... ...koje su okruživala sa svih strana... ... hravo a bezstarostne poletoval z kvetu na kvet... ...poletno i bezbrižno je leteo sa cveta na cvet... ...mal by si si ż času na čas urobit’olejový zábal... ...trebalo bi da $\underline{s}$ vremena na vreme staviš uljno pakovanje... ...z hlbky duše veril, že je to naozaj tak... ... $\underline{\text { iz }}$ dubine duše je verovao da je to zaista tako...

Predložkou z možno vyjadrit' spôsob aj v ustálených spojeniach kráčat'z nohy na nohu, z ruky do ruky, zo dřa na den̆. V srbčine v tomto kontexte bude ekvivalentná predložka iz: $\underline{i z}$ dana u dan, $\underline{i z}$ ruke u ruku.

\subsection{Prostriedok, nástroj}

Slovenská predložka $\mathrm{z}, \mathrm{,}$ spojeniach $\mathrm{s}$ genitívom podstatných mien pomenúvajúcich substancie, ktoré možno chápat’ ako prostriedok alebo nástroj, vyjadruje význam prostriedku alebo nástroja“ (MASS, 2010 : 292). Uvedenému slovenskému významu v srbčine zodpovedá niekol'ko konštrukcií: významovo ekvivalentná konštrukcia predložky iz v spojení s genitívom, väzba od $+\mathrm{G}$ a bezpredložková väzba, napr. ...,,iste si viete predstavit', že nežila len zo svojho platu, “... ...,,sigurno možete da zamislite da nije živela samo od svoje plate"... Neodvetil, iba si otvoril pivo a napil sa priamo z flaše. Nije odgovorio, samo je otvorio pivo i popio gutljaj direktno iz flaše. „Nechápem, ako vám údajná slepota môže bránit' počut' výstrel z dela." "Ne shvatam kako vam navodno slepilo može smetati da čujete topovski pucanj."

\subsection{Zretel'}

Predložka z vyjadruje zretel' pri prirovnávaní so superlatívmi adjektív a adverbií, napr. „Mária bola najkrajšia z celej triedy“ (MASS, 2010 : 293). V srbčine máme spojenie_najlepša iz razreda. V spojeniach typu z hladiska, zo stanoviska, zo stránky atd'. tiež ide o vyjadrovanie zretel'a. V tomto kontexte $\mathrm{v}$ analyzovanýh 
textoch v srbčine je ekvivalentná predložka s/sa, napr. Obec a jej okolie je z $\underline{\text { bo- }}$ tanickej stránky vd'ačným objektom pre milovníkov prírody... Selo i njegova okolina je sa botaničkog stanovišta idealno mesto za ljubitelje prirode... Čiže z ich

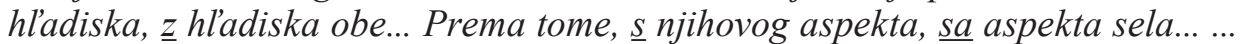
On sa totiž o cudie ženy nikdy nezaujimal... povedala by som, zz nejakej erotickej stránky... Njega, naime, druge žene nikada nisu zanimale... rekla bih... sa erotske strane...

\subsection{Predmet (odlukový, partitívny genitív) pri slovesách}

Predložka z sa v slovenčine používa s tzv. partitívnym, či odlukovým genitívom pri slovesách, ktoré implikujú význam oddelenia časti od celku a tiež aj pri slovesách so sémantikou zbavovania sa niečoho alebo zmeny stavu (MASS, 2010). V srbčine sa ako ekvivalent prvého významu najčastejšie vyskytla bezpredložková väzba. Ked' ide o sémantiku zmeny stavu vyskytla sa významovo ekvivalentá predložka iz, napr. ...zarehotal sa a logol si z piva. ...zacerekao se i cugnuo pivo. Radšej si konečne odkroj z chleba... Bolje konačno iseci hleb... ...nemajte strach, z nosa vám neodhryznem... ...ne brinite, neću vam odgristi nos... ...rýchlostou, ktorá opät' prebrala z letargie zdravý pud sebazáchovy slečnej Lapšanskej. ...brzinom koja je ponovo prenula iz letargije instinkt samoočuvanja gospođice Lapšanske.

\subsection{Interferencia}

Vo vojvodinských médiách sme zaznamenali nenáležité spojenie: Ostrov Mindanao sa ešte stále zotavuje od následkov najsilnejšieho tajfúna, ktorý zasiahol Filipiny tohto roku, ktoré vzniklo podl'a srbskej konštrukcie: oporavljati se od posledica tajfuna. Aj ked' predložka od v slovenčine tiež vyjadruje príčinu, dokonca najčastejšie si v tomto význame korešponduje so srbskou predložkou $o d, \mathrm{v}$ tomto prípade je použitá nenáležite. Ide o jazykový úzus, ktorý treba rešpektovat' a použit'správnu väzbu s predložkou z: zotavovat'sa z následkov.

\section{Zhrnutie}

Predložky od, do a z zarad'ujeme do skupiny primárnych predložiek a v oboch skúmaných jazykoch sa viažu s genitívom. Predložky od a do sú v oboch jazykoch úplne formálne a zvukovo zhodné. Slovenská predložka do je kontaktová a vyjadruje uskutočňovanie kontaktu deja s vnútrom objektu. Srbská predložka do je pozičná. Spoločný význam v oboch jazykoch je význam časovej, miestnej a číselnej hranice. Môže vyjadrovat' rozličné významy: smerovanie dovnútra niečoho alebo na niečo, spôsob, mieru, prostriedok, účel, ciel'. Slovenskej predložke do v srbčine je ekvivalentná predložka do, u+A, na, o+A, za. Predložka od sa v oboch jazykoch zarad’uje k pozičným predložkám a vyjadruje rušenie pozície deja vzhl'adom na blízkost' objektu. Predložka v spojení s menom v genitíve vyjadruje priestorové alebo časové východisko, príčinu, dôvod, pôvod, spôsob, zretel', účel, ciel'. Z dokladov vyplýva, že slovenskej predložke od v srbčine je ekvivalentná rovnozvučná predložka, v niektorých dokladoch sa vyskytlo bezpredložkové 
spojenie. Mieru možno vyjadrit' spojením predložiek od - do, od - po. Slovenská predložka z nemá v srbčine formovo identický ekvivalent, ale významovo jej zodpovedajú predložky iz, s, sa, od. Predložku z zarad'ujeme ku kontaktovým predložkám, lebo vyjadruje rušenie kontaktu deja s vnútrom alebo s povrchom objektu. Predložka z v spojení s menom v genitíve vyjadruje miestne vzt’ahy, čas, pôvod, materiál, príčinu, dôvod, spôsob, mieru, prostriedok, zretel'.

\section{LITERATÚRA}

Dvonč, L., Horák, G., Miko, F., Mistrík, J., Oravec, J., Ružička, J. \& Urbančok, M.(1966). Morfológia slovenského jazyka. Bratislava: SAV.

Horák, E. (1971). Predložky zbog, od a iz v spisovnej srbochorvátčine a ich ekvivalenty pre, od a z v spisovnej slovenčine. U: Novaković, B. (ured.) (1971). Godišnjak Filozofskog fakulteta u Novom Sadu. (str. 487 - 502) Novi Sad: Filozofski fakultet.

Horák, E. (1972). Predložkový systém spisovnej slovenčiny. Slovenská reč, 37, 341-354.

Horák, E. (1973). Kontrastívna analýza predložkového systému spisovnej srbochorvátčiny a spisovnej slovenčiny. Slavica Slovaca, 1, 75-92.

Horák, E. (1989). Východiská pre konfrontáciu predložkového systému slovenčiny s inými jazykmi. U: Mistrík, J. (red.) Studia Academica Slovaca. (str. 167-183). Bratislava: Alfa

Kerd’o, J. (1989). Kontrastívny opis primárnych slovenských a rumunských predložiek. U: Mistrík, J. (red.) (1989). Studia Academica Slovaca. 18. (str. 239-251). Bratislava: Alfa.

Krátky slovník slovenského jazyka (1987). Kačala, J., Pisárčiková, M. (red.) Bratislava: Veda.

Makišová, A. (1990). Predlozi u usmenim iskazima vojvođanskih Slovaka. U: Dudok, D. (ured.) (1990). Kontrastivna jezička istraživanja (str. 347-353). Novi Sad: Filozofski fakultet.

Milecová, N. (1989). Konfrontácia predložkového systému slovenčiny a ruštiny. U: Mistrík, J. (red.) (1989). Studia Academica Slovaca. 18. (str. 321-335). Bratislava: Alfa.

Myjavcová, M. (2009). Slovenská jazyková čítanka. Báčsky Petrovec: Slovenské vydavatelské centrum.

Rečnik srpskoga jezika (2007). Nikolić, M. (ured.) Novi Sad: Matica srpska.

Ružičková, E. (1989). Predložkový systém slovenčiny v konfrontácii s angličtinou. U: Mistrík, J. (red.) (1989). Studia Academica Slovaca. 18. (str. 461-479). Bratislava: Alfa.

Stevanović, M. (1975). Savremeni srpskohrvatski jezik I. Beograd: Naučna knjiga.

Taraba, J. (1989). Ku konfrontačnému opisu slovenských a francúzskych predložiek na báze invariantného významu. U: Mistrík, J. (red.) (1989). Studia Academica Slovaca. 18. (str. 527543). Bratislava: Alfa.

Vaňko, J. (2010). Fixátory dependencie. U: Dolník, J. (editor) (2010). Morfologické aspekty súčasnej slovenčiny (str.265-315) Bratislava: Veda. 
Ana Makišova, Jana Kovačova

\title{
PREDLOZI OD, DO I Z U SLOVAČKOM I NJIHOVI EKVIVALENTI U SRPSKO
}

\begin{abstract}
REZIME
U radu smo analizirali primarne predloge $o d$, do i z u slovačkom jeziku i njihove ekvivalente u srpskom jeziku. Ovi predlozi se spajaju sa genitivom. Predlozi od i do u oba jezika se slažu na planu forme. Slovački predlog do izražava kontakt, dok srpski predlog do označava poziciju. Predlogom do u oba jezika označavamo vremensku granicu, mesto završetka kretanja, položaj, kretanje ka unutrašnjosti, način, cilj, svrhu, približnu granicu. U srpskom jeziku ekvivalentni su predlozi $d o, u, n a, z a$. Predlog od u oba jezika svrstavamo među pozicione predloge. Izražavamo mesto početka radnje, vreme početka radnje, uzrok, povod, obzir, cilj, svrhu. Navedena značenja u srpskom jeziku izražavamo predlozima $o d, o d-d o, o d-p o$. Predlogom $z$ izražavamo mesto, polaznu tačku, vreme od kojeg nešto počinje, poreklo, motiv, uzrok, materiju, građu od koje je nešto napravljeno. Slovačkom predlogu $z$ semantički ekvivalentni su predlozi $i z, s, s a, o d$. U radu smo naveli i pojave interferencije sa pomenutim predlozima.

Ključne reči: predlog, srpski jezik, slovački jezik, interferencija.
\end{abstract}

Ana Makišova, Jana Kovačova

\section{PREPOSITIONS DO, OD AND Z IN SLOVAK AND THEIR EQUIVALENTS IN SERBIAN}

\begin{abstract}
SUMMARY
The paper analyzed primary prepositions od, do and $\mathrm{z}$ in Slovak and their equivalents in Serbian. These prepositions are used with the genitive case. In both languages prepositions $o d$ and $d o$ are formally the same. The Slovak preposition do expresses contact, while the Serbian preposition do marks a position. The preposition do in both languages marks a temporal boundary, a point of the end of motion, a position, a movement towards the interior, a manner, an aim, a purpose, an approximate boundary. In the Serbian language the equivalent prepositions are $d o, u, n a, z a$.The preposition $o d$ is a position preposition in both languages and is used to express a point of the beginning of an action, the time of the beginning of an action, a cause, a motive, an aim, a purpose. These meanings are expressed with prepositions od, od-do, od-po in Serbian. The preposition $z$ expresses a place, a point of origin, a time when something begins, an origin, a motive, a cause, a matter, a material something is made of. The Serbian semantic equivalents of the Slovak preposition $z$ are $i z, s, s a, o d$. The paper also lists interference that occurs when these prepositions are used.

Key words: preposition, Serbian language, Slovak language, interference.
\end{abstract}

